
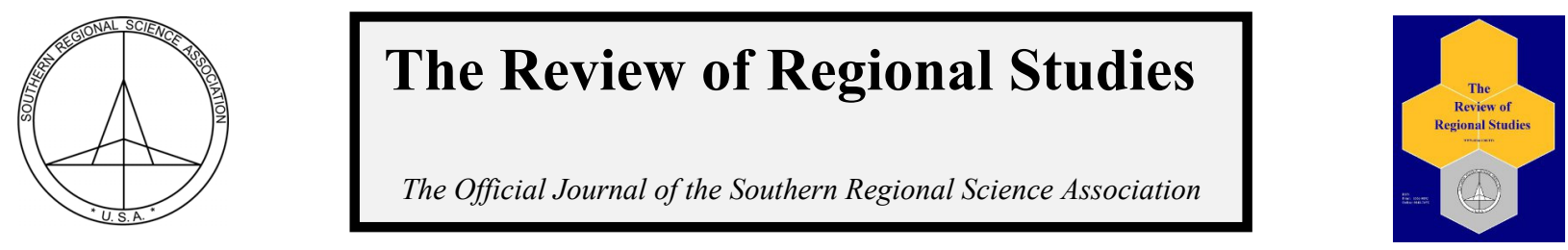

\title{
The Effects of High Growth on New Business Survival
}

\author{
Taelim Choi ${ }^{\mathrm{a}}$, Anil Rupasingha ${ }^{\mathrm{b}}$, John C. Robertson ${ }^{\mathrm{c}}$, and Nancey Green Leigh ${ }^{\mathrm{d}}$ \\ ancheon Development Institute, South Korea \\ ${ }^{b}$ Economic Research Service, United States Department of Agriculture, USA \\ ${ }^{c}$ Federal Reserve Bank of Atlanta,USA \\ ${ }^{d}$ School of City and Regional Planning, Georgia Institute of Technology,USA
}

\begin{abstract}
High-growth, young businesses have received increased attention in the research and policy sphere because of their job creation potential. However, relatively less attention has focused on the effects of high growth on firm survival and its implications for job creation and destruction dynamics. This paper analyzes the effect of high employment growth on the survival of new establishments and the survival patterns of high-growth firms in the U.S. State of Georgia. We use the National Establishment Time-Series (NETS) data to examine the new establishments that started between 1990 and 1999 and trace their employment dynamics through 2008. We analyze how early-stage employment growth impacts the survival rate of these establishments. Our analysis provides evidence that high employment growth early in their life cycle significantly reduces the likelihood of subsequent failure.
\end{abstract}

Keywords: high growth, survival analysis, young business

JEL Codes: L25; L29; M13

\section{INTRODUCTION}

Because of their extraordinary potential for job creation, young high-growth firms have been the focus of increasing attention. These firms, often referred to as "gazelles," are defined by the Eurostat-OECD $(2007$, p. 63$)$ as "All enterprises up to 5 years old with average annualized growth greater than $20 \%$ per annum, over a three year period." A strand of literature on highgrowth firms consistently finds that a small portion of fast-growing businesses accounts for the lion's share of job creation (Clayton et al., 2013; Stangler, 2010; National Endowment for Science, Technology and the Arts (NESTA), 2009; Acs, 2011). Essential characteristics of these firms are that they are young (Henrekson and Johansson, 2010) and that they generate a disproportionate number of new job opportunities (Acs and Armington, 2004; Fritsch and Mueller, 2004).

The significance of high-growth firms has led to a series of empirical studies that focus on their characteristics (Clayton et al., 2013; Stangler, 2010), heterogeneous growth patterns (Delmar, Davidsson, and Gartner, 2003), the persistence of high growth (Daunfeldt and

Choi is a Research Fellow at Incheon Development Institute. Rupasingha is an Economist at the Economic Research Service, United States Department of Agriculture. Robertson is a Senior Policy Adviser and Economist at Federal Reserve Bank of Atlanta, USA. Leigh is a Professor of School of City and Regional Planning at Georgia Institute of Technology, USA. The views expressed here are those of the authors and should not be attributed to Incheon Development Institute, the Economic Research Service, US Department of Agriculture, Federal Reserve Bank of Atlanta or Georgia Institute of Technology. Corresponding Author: A. Rupasingha E-mail: anil.rupasingha@ers.usda.gov

(C) Southern Regional Science Association 2017.

ISSN 1553-0892, 0048-749X (online)

www.srsa.org/rrs 
Halvarsson, 2012), and the determinants of fast-growing firms (Lopez-Garcia and Puente, 2012). However, little is known about the effect of high employment growth on firm survival, the survival patterns of young, high-growth firms, and the firm-level, industry-level, and regionallevel characteristics that may affect the survival rate of high-growth firms. Relatively few studies have addressed the risk that fast-growing firms potentially carry. De Kok and Zhou (2012) contend that fast-growing firms may be at a risk of failure when they experience financial and managerial problems stemming from the abrupt expansion of their organization. Storey (2011) highlights that the growth patterns of small, young firms are temporally volatile in a short to medium period. Mohr and Garnsey (2011) argue that a period of high growth which excessively stretches the firm's capacities may be followed by zero growth or sudden failure. A high vulnerability for failure may lead to considerable reduction in job creation potential and regional economic development opportunities.

The purpose of this study is to examine the effect of high employment growth on the subsequent survival of new establishments and the survival pattern of fast-growing, young establishments after a high-growth period. More specifically, using data for the State of Georgia in the United States, we first investigate the effect of high employment growth during the first three years of operation on the later survival of the firms, with a particular focus on identifying an elevated risk of failure in new establishments that experience a rapid expansion and exhibit a volatile growth pattern. Next, we compare the determinants of the hazard rate for young highgrowth firms to those of their counterparts. We also describe the dynamic process of job creation and destruction driven by fast-growing start-ups. In so doing, we find factors that appear to be important for the survival of new businesses. This sets the stage to gain some insights into possible entrepreneurship policy reform redirected toward the retention and support of start-ups with high growth potential (Shane, 2009; Mason and Brown, 2013; Santarelli and Vivarelli, 2007).

We find that high employment growth early in the year and the current size of a business are critical characteristics for reducing the risk of failure. We also find that the high employment growth effect is nonlinear. This suggests that, after a point, high growth increases the risk of failure for new establishments. When we divide the sample between high-and low-growth businesses, we find that the effects of initial high employment growth and its nonlinear effects disappear for the high-growth sample. In other words, once a new high-growth establishment has grown at a certain pace, its risk of failure does not depend on the prior variation in employment growth rates. However, the relationships largely hold for the non-high-growth sample. Thus, the causes of establishment failure differ between the two samples

The rest of this paper is organized as follows. In the next section, we discuss relevant literature and formulate hypotheses regarding the effects of high growth. Section 3 briefly introduces the longitudinal establishment-level data used in the paper. In Section 4 we describe growth and survival patterns of new establishments, especially in terms of their size and age. Section 5 is a discussion of results from the survival analysis, and Section 6 concludes with a brief summary and some policy insights.

\section{LITERATURE REVIEW AND CONCEPTUAL FRAMEWORK}

Many studies have examined the growth and survival patterns of firms. They tend to give prominence to the age and the size of the firm as factors associated with growth and survival. Studies have consistently found that growth is systemically related to the age and size of a firm

(C) Southern Regional Science Association 2017. 
(Evans, 1987; Dunne and Hughes, 1994; Farinas and Moreno, 2000) and that the growth rate declines as age and size increase. Empirical findings have rejected Gibrat's Law, which states that growth is independent of the size of the firm (Sutton, 1997).

The most common finding in the literature that investigates the factors associated with the survival of the firm is that the hazard rate decreases with firm size and age (Audretsch and Mahmood, 1995; Mata, Portugal, and Guimaraes, 1995; Kosová and Lafontaine, 2010; Pérez, Llopis, and Llopis, 2004). This implies that smaller and younger firms face a higher risk of failure. Nonetheless, several studies have indicated that the linear relationship between survival and firm age and size does not hold in some cases. Pérez, Llopis, and Llopis (2004) found that the risk of failure was higher both in firms less than 10 years old and in firms more than 50 years old. Agarwal and Audretsch (2001) showed that the relationship between the size and the survival rate of a firm is affected by the technological features of a particular industry and the stage of the life cycle. They found that, in a mature, high-tech industry, smaller firms are more likely to survive if the firms are in a niche market. Klepper and Thompson (2006) explained that the growth rate of firms varies according to their ability to exploit the opportunities of a submarket-firms can distinguish themselves by their level of technology or service, the segmentation of their customer base, and their geographic area. They argued that as opportunities for firms to participate in submarkets expand with age, so does the likelihood of their survival.

The studies that are more relevant to this paper are those that study the relationship between growth and survival of high-growth firms. Early research on growth and survival suggests that a fast-growing firm that receives a favorable market response and accumulates a resource base is more likely to survive (Jovanovic, 1982; Mata, Portugal, and Guimarães, 1995; Audretsch and Mahmood, 1995). Dunne, Roberts, and Samuelson (1989) examined the survival rate by groups with different growth rates of employment and found that the likelihood of failure was higher for manufacturing plants with declining employment than those plants with stable employment. They also found that the likelihood of failure was the same for plants with expanding employment as those with stable employment. Phillip and Kirchhoff (1989) categorized the survival rates of new U.S. establishments with less than 500 employees according to whether their growth rates were zero, low, medium, or high. They found that the six-year survival rates of firms with low, medium, and high growth rates were similar while the survival rate of firms with zero growth was significantly lower. De Kok and Zhou (2012) discovered an inverted U-shaped relationship between employment growth and survival rates in their analysis of firms in the Netherlands. They argued that firms with high employment growth faced higher risk associated with the demands resulting from rapid managerial and organizational change. Lotti, Sanatarelli, and Vivarelli (2003) provided empirical evidence that small entrants were pushed to grow until they reached an acceptable minimum efficient size, and once they reached a size equivalent to that of a large entrant, the exit patterns of small-sized entrants were similar to those of large-sized entrants. Recent empirical analyses that examined serial growth patterns suggest another scenario of growth trajectory. These studies found that small firms experience erratic and volatile employment growth and those that experience high growth are unlikely to repeat the high level of performance in the following period (Coad, 2007; Parker, Storey, and Witteloostuijn, 2010; Daunfeldt and Halvarsson, 2012).

From the empirical and theoretical research discussed above, we have identified several stylized patterns of new firm growth and survival: young firms tend to grow faster, and they are generally subject to a high risk of failure, possibly because of their size disadvantage. Still, 
certain market conditions, such as the existence of differentiated submarkets, result in exceptional survival patterns. Finally, the relationship between growth and survival rates is not linear. For example, fast-growing firms may be at a higher risk of failure because of temporal financial constraints and managerial crises triggered by the rapid expansion of an organization or single product plants.

By synthesizing the above empirical findings, we have identified several testable hypotheses regarding the survival patterns of young high-growth firms. First, we will test whether initial high growth reduces the likelihood of failure over the life cycle of new establishments. In addition, we have hypothesized that the relationship between employment growth and hazard rate is U-shape. The presence of risk in fast growth may lead to a non-linear relationship between survival and employment growth, which we will examine empirically.

\section{DATA}

To conduct the survival analysis, we set up a dataset comprised of new establishments started between 1990 and 1999 in Georgia using the National Establishment Time-Series (NETS) data. ${ }^{1}$ Since the NETS tracks individual records of establishments over time, it provides useful, comprehensive data pertaining to entry, employment growth, and exit of individual establishments. The quality of the NETS data, however, has been called into question (Davis et al., 1996). Neumark, Zhang, and Wall (2007) examined the quality of the California NETS data on three issues: measurement of employment level and its change, business relocation, and identification of entry of new business. Choi, Robertson, and Rupasingha (2013) followed the same approach to assess the quality of the NETS data for Georgia. Interested readers can refer to this paper, which provides detailed results and a discussion about the quality of the NETS data for Georgia. ${ }^{2}$

A refined data set based on the method employed in Choi, Robertson, and Rupasingha (2013) is used in the survival analysis in this study. From this dataset, we drew establishmentlevel information such as the duration of new establishments, entry size, and organizational type. In addition, we incorporated time-varying variables such as current employment, the industry entry rate, and local economic characteristics. In the following section, we present a descriptive analysis of new establishment formation, growth, and survival patterns.

\section{A DESCRIPTIVE ANALYSIS OF NEW ESTABLISHMENTS AND NEW HIGH GROWTH ESTABLISHMENTS IN GEORGIA}

\subsection{Entry, Growth, and Exit Patterns of New Establishments}

Start-ups are an important source of job creation and destruction in Georgia. During the 1990s, about 165,000 new establishments started in Georgia, creating nearly two million jobs.

\footnotetext{
${ }^{1}$ We investigated establishment-level exit and growth patterns instead of firm-level patterns because establishment-level changes are better reflected by the geographical differences that affect the likelihood of a business's exit. Since many small, new businesses are susceptible to local economic conditions, our regression model for survival analysis includes county-level variables.

${ }^{2}$ The number of establishments in the NETS database significantly differs from the number of establishments reported in government statistics such as the Quarterly Census of Employment and Wages (QCEW) and Business Dynamics Statistics (BDS). The details of these differences and how they can be reconciled are explained in detail by Choi, Robertson, and Rupasingha (2013).
}

(C) Southern Regional Science Association 2017. 


\section{Table 1: Dynamics of Exit and Job Destruction of New Establishments in Georgia over 10 Time Intervals}

\begin{tabular}{crrrrrr}
\hline \hline $\begin{array}{c}\text { Interval } \\
\text { (year) }\end{array}$ & $\begin{array}{c}\text { Total new } \\
\text { establishment } \\
\text { remained }\end{array}$ & $\begin{array}{c}\text { Number of } \\
\text { jobs retained }\end{array}$ & $\begin{array}{c}\text { Number of } \\
\text { establishments } \\
\text { exited }\end{array}$ & $\begin{array}{c}\text { Job } \\
\text { destruction } \\
\text { from exit }\end{array}$ & Exit rate & $\begin{array}{c}\text { Share of cumulated } \\
\text { exiting new } \\
\text { establishment }\end{array}$ \\
\hline $1-2$ & 164,894 & $1,973,259$ & 17,999 & 132,291 & $10.9 \%$ & $10.9 \%$ \\
$2-3$ & 146,895 & $1,856,462$ & 24,170 & 161,911 & $16.5 \%$ & $25.6 \%$ \\
$3-4$ & 122,725 & $1,706,141$ & 16,346 & 150,228 & $13.3 \%$ & $35.5 \%$ \\
$4-5$ & 106,379 & $1,577,828$ & 13,129 & 137,736 & $12.3 \%$ & $43.4 \%$ \\
$5-6$ & 93,250 & $1,473,598$ & 8,476 & 109,148 & $9.1 \%$ & $48.6 \%$ \\
$6-7$ & 84,774 & $1,387,049$ & 6,678 & 94,929 & $7.9 \%$ & $52.6 \%$ \\
$7-8$ & 78,096 & $1,319,222$ & 5,018 & 83,182 & $6.4 \%$ & $55.6 \%$ \\
$8-9$ & 73,078 & $1,259,916$ & 4,244 & 71,643 & $5.8 \%$ & $58.2 \%$ \\
$9-10$ & 68,834 & $1,190,922$ & 3,477 & 58,011 & $5.1 \%$ & $60.3 \%$ \\
$10-11$ & 65,357 & $1,147,056$ & 4,246 & 76,434 & $6.5 \%$ & $62.9 \%$ \\
\hline \hline
\end{tabular}

Source: NETS and authors' calculations

However, a large number of new jobs were lost due to the high failure rate of new establishments during their first five years. Table 1 represents how jobs created at the birth of new establishments were destroyed when the establishments failed over a ten-year period. The numbers presented in Table 1 indicate that about eleven percent of new establishments created between 1990 and 1999 failed and a total of 132,291 jobs were lost during the first-year (first to second year interval) of the opening. This exit rate and associated job loss were even higher in the second period. Almost half of the newly created establishments disappeared before completing six years in operation and only about 37 percent of the start-ups survive after ten years of operation. These patterns are somewhat similar to national trends in the U.S., where the survival rate of new firms is about 50 percent after five years and 33 percent after ten years. ${ }^{3}$

In the study of growth and survival of new establishments, the size and the age of the business have been key attributes of interest (Geroski, 1995; Haltiwanger et al., 2013; Stam, 2010). We investigate the growth and survival patterns of new establishments by size and age in Figure 1. First, we examine the relationship between growth rate and establishment size. We use two size categories: the initial size (or the size at incipience) and the average size 4 (or the mean of employment in the first and third years). When we use the initial size, the relationship between the size and the growth rate is clearly negative: the smaller the entry size, the higher the growth rate and vice versa. However, when we use the average size, the shape of the relationship between size and growth rate becomes more or less an inverted U-shape. This pattern is consistent with the findings of Haltiwanger, Jarmin, and Miranda (2013), which analyzed data from the Census Bureau Longitude Business Database. ${ }^{5}$ Next, we examine the variation of growth rate across ages. On average, the growth rate is the highest in the 3-6 year age group and declined for the 6-9 and 9-12 age groups as shown in the top right-hand graph in Figure 1.

\footnotetext{
${ }^{3}$ Source: U.S. Small Business Administration; http://www.sba.gov/sites/default/files/FAQ_Sept_2012.pdf

${ }^{4}$ Average size can control for any regression-to-mean effect (Haltiwanger et al., 2013).

${ }^{5}$ Neumark, Wall, and Zhang (2011) also find that small establishments create more jobs when they did not control for the effects of age, indicating a negative relationship between employment growth and size in both initial and average size categorizations for the U.S.
}

(C) Southern Regional Science Association 2017. 
Figure 1: Growth and Exit Patterns by Establishment Size, Age, and Initial Growth Rate
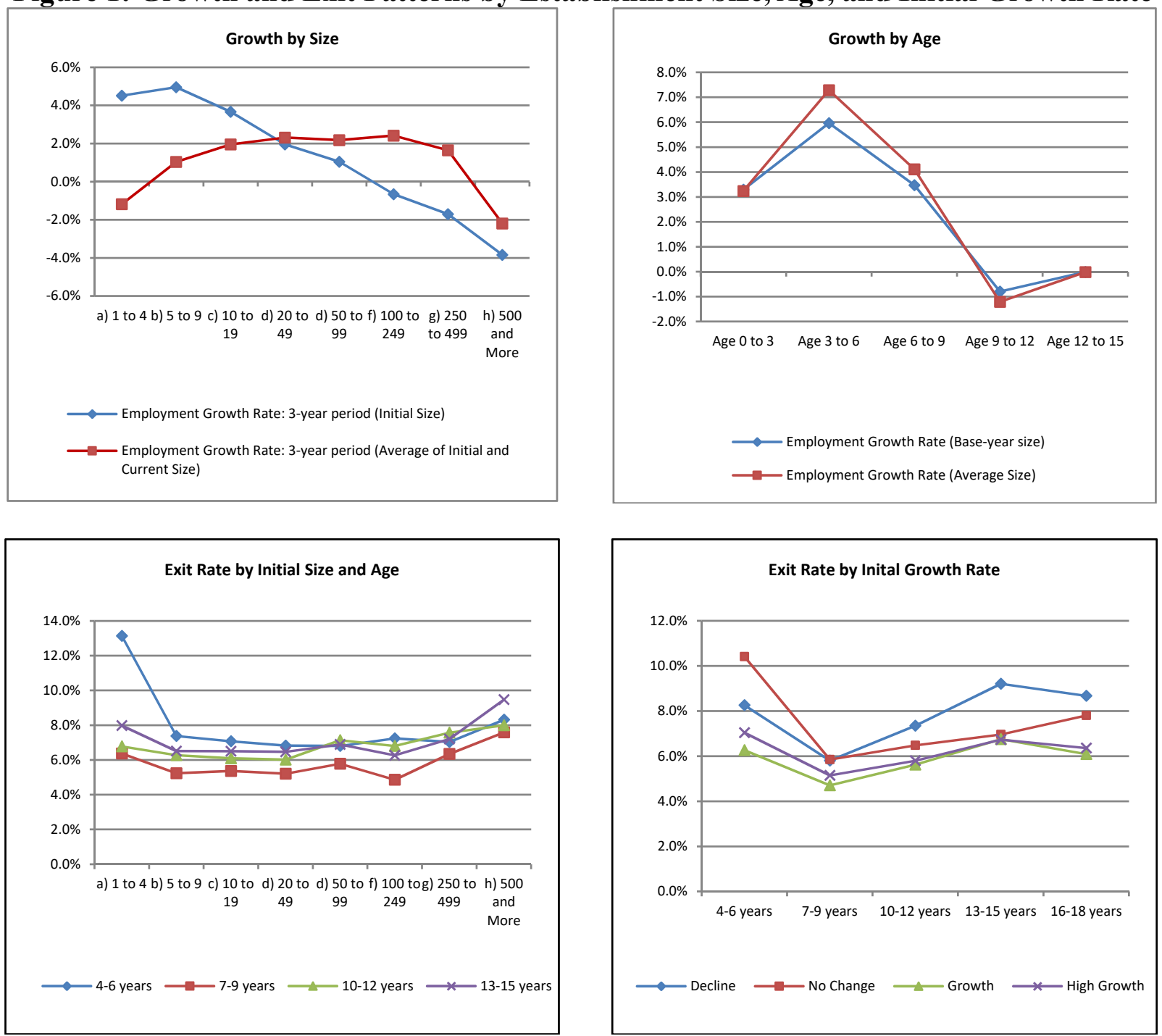

Source: NETS and the authors' calculations

Note: We calculate the employment growth rate in the first three years. For analytical consistency, we exclude establishments that exit in the first or second years in the graphical analysis so that there is no case of exit in the one to three year interval in the bottom two graphs.

We also identify exit patterns according to the initial size and age of the firm. The exit rate is significantly higher in the smallest, youngest group compared to other groups, as shown in the bottom left-hand graph in Figure 1. The exit rates of mid-size groups (from 5-9 to 100-250 employees) are similar to one another, but the exit rates increase in the large-size and old-age categories. The increase in the exit rate in the large-size group might be associated with the organizational type. For example, a multi-establishment firm may more often be engaged in closing down large inefficient plants and reallocating the employees to other branch plants. The reallocation activity can be a contributing factor to the higher exit rate for the large-size establishments.

The bottom right-hand graph in Figure 1 shows the relationship between initial growth rates and exit patterns. The exit rates of new establishments in growth and high-growth categories are lower than those establishments with no employment change or a decline over 
their life-cycles. The exit rates between the growth and high-growth categories do not differ much. In summary, these graphical analyses highlight growth and exit patterns of new establishments in Georgia that are consistent with the stylized growth and survival behaviors in the previous literature: variations in the growth rate and the exit rate are explained by size and age; growth and exit rates are higher for young and small establishments; and the exit rate decreases as time passes for growing new establishments.

\subsection{Characteristics of New High-growth Establishments}

To identify the new establishments that experienced high growth, we used Clayton et al.'s (2013) definition. ${ }^{6}$ According to this definition, firms with more than ten employees are classified as high-growth if their employment growth rates exceeded 72.8 percent over a threeyear period, and firms with fewer than ten employees are classified as high-growth if they added eight or more employees to their rosters over a three-year period. ${ }^{7}$ When we applied this definition to the refined Georgia NETS data, we classified 8,314 out of 164,894 new establishments that started between 1990 and 1999 as high-growth, representing about 5 percent of new establishments in the same period. Based on entry size, the vast majority (over 80 percent) of high-growth new establishments (HGNEs) were small in size (with 1-19 employees) and of this, 25 percent were establishments that had 1-4 employees (Table 2). In contrast, the share of new high-growth establishments that employed 500 or more employees was about 0.2 percent.

Table 2: New Establishments and High Growth by Size

\begin{tabular}{|c|c|c|c|c|c|}
\hline Entry Size & $\begin{array}{l}\text { Total number } \\
\text { of new est. }\end{array}$ & $\begin{array}{c}\text { Number of } \\
\text { HGNEs }\end{array}$ & $\begin{array}{c}\text { New est. as a } \\
\text { percentage of all } \\
\text { new est. }\end{array}$ & $\begin{array}{l}\text { HGNEs as a } \\
\text { percentage of } \\
\text { all HGNEs } \\
\end{array}$ & $\begin{array}{l}\text { HGNEs as a } \\
\text { percentage of } \\
\text { all newest. }\end{array}$ \\
\hline a) 1 to 4 & 95,372 & 2,110 & $57.8 \%$ & $25.4 \%$ & $2.2 \%$ \\
\hline b) 5 to 9 & 34,086 & 2,667 & $20.7 \%$ & $32.1 \%$ & $7.8 \%$ \\
\hline c) 10 to 19 & 17,935 & 1,966 & $10.9 \%$ & $23.6 \%$ & $11.0 \%$ \\
\hline d) 20 to 49 & 11,406 & 1,098 & $6.9 \%$ & $13.2 \%$ & $9.6 \%$ \\
\hline e) 50 to 99 & 3,458 & 273 & $2.1 \%$ & $3.3 \%$ & $7.9 \%$ \\
\hline f) 100 to 249 & 1,924 & 152 & $1.2 \%$ & $1.8 \%$ & $7.9 \%$ \\
\hline g) 250 to 499 & 435 & 35 & $0.3 \%$ & $0.4 \%$ & $8.0 \%$ \\
\hline h) 500 to 999 & 167 & 7 & $0.1 \%$ & $0.1 \%$ & $4.2 \%$ \\
\hline i) 1000 & 111 & 6 & $0.1 \%$ & $0.1 \%$ & $5.4 \%$ \\
\hline Total & 164,894 & 8,314 & $100 \%$ & $100 \%$ & $5.0 \%$ \\
\hline
\end{tabular}

Source: NETS and authors' calculations

\footnotetext{
${ }^{6}$ The definition of "high growth" differs based on the method of calculating the growth over time (absolute or percentage change) and which type of measurement (employment, revenue, or productivity) is employed (see Delmar, Davidsson, and Gartner, 2003; Daunfeldt et al., 2010 for details). The OECD definitions based on the percentage growth criterion (shown in the introduction section) exclude firms that have fewer than ten employees because it is easier for such firms to satisfy the percentage growth criterion. Clayton et al. (2013) seek to overcome this problem.

${ }^{7}$ As one reviewer pointed out, the definition of a high growth firm biases toward small firms, because they have a low-base level employment. For example, a firm with one employee can meet the high growth firm criteria by hiring one additional employee over the three years. A firm with ten employees would need to add eight employees over the three years. The OECD definition is designed to overcome this issue but somewhat unfairly excludes the firms that are smaller but may be growing at a high-growth rate. Including firms with fewer than ten employees that added eight or more employees to the roster tries to capture those firms that are smaller but growing at a faster rate.
} 
Table 3: New Establishments and High Growth by Industry

\begin{tabular}{|c|c|c|c|c|c|}
\hline Industry Description & $\begin{array}{c}\text { Total } \\
\text { number of } \\
\text { new est. }\end{array}$ & $\begin{array}{l}\text { Number of } \\
\text { HGNEs }\end{array}$ & $\begin{array}{l}\text { New est. as a } \\
\text { percentage of } \\
\text { all new est. }\end{array}$ & $\begin{array}{l}\text { HGNEs as a } \\
\text { percentage of } \\
\text { all HGNEs }\end{array}$ & $\begin{array}{l}\text { HGNEs as a } \\
\text { percentage of } \\
\text { all new est. }\end{array}$ \\
\hline Agriculture, forestry, fishing, and hunting & 1,292 & 43 & $0.8 \%$ & $0.5 \%$ & $3.3 \%$ \\
\hline extraction & 137 & 9 & $0.1 \%$ & $0.1 \%$ & $6.6 \%$ \\
\hline Utilities & 236 & 23 & $0.1 \%$ & $0.3 \%$ & $9.7 \%$ \\
\hline Construction & 16,298 & 913 & $9.9 \%$ & $11.0 \%$ & $5.6 \%$ \\
\hline Manufacturing & 1,612 & 160 & $1.0 \%$ & $1.9 \%$ & $9.9 \%$ \\
\hline Wholesale trade & 18,724 & 1,419 & $11.4 \%$ & $17.1 \%$ & $7.6 \%$ \\
\hline Retail trade & 20,792 & 744 & $12.6 \%$ & $8.9 \%$ & $3.6 \%$ \\
\hline Transportation and warehousing & 13,793 & 514 & $8.4 \%$ & $6.2 \%$ & $3.7 \%$ \\
\hline Information & 5,753 & 404 & $3.5 \%$ & $4.9 \%$ & $7.0 \%$ \\
\hline Finance and insurance & 8,970 & 469 & $5.4 \%$ & $5.6 \%$ & $5.2 \%$ \\
\hline Real estate and rental and leasing & 6,442 & 292 & $3.9 \%$ & $3.5 \%$ & $4.5 \%$ \\
\hline $\begin{array}{l}\text { Professional, scientific, and technical } \\
\text { services }\end{array}$ & 19,438 & 1,146 & $11.8 \%$ & $13.8 \%$ & $5.9 \%$ \\
\hline enterprises & 182 & 18 & $0.1 \%$ & $0.2 \%$ & $9.9 \%$ \\
\hline $\begin{array}{l}\text { Administrative and support and waste } \\
\text { management and remediation services }\end{array}$ & 11,497 & 587 & $7.0 \%$ & $7.1 \%$ & $5.1 \%$ \\
\hline Educational services & 1,131 & 76 & $0.7 \%$ & $0.9 \%$ & $6.7 \%$ \\
\hline Health care and social assistance & 12,680 & 633 & $7.7 \%$ & $7.6 \%$ & $5.0 \%$ \\
\hline Arts, entertainment, and recreation & 3,270 & 119 & $2.0 \%$ & $1.4 \%$ & $3.6 \%$ \\
\hline Accommodation and food services & 8,807 & 501 & $5.3 \%$ & $6.0 \%$ & $5.7 \%$ \\
\hline Other services & 13,840 & 244 & $8.4 \%$ & $2.9 \%$ & $1.8 \%$ \\
\hline Total for all sectors & 164,894 & 8,314 & $100.0 \%$ & $100.0 \%$ & $5.0 \%$ \\
\hline
\end{tabular}

Source: NETS and authors' calculations

Table 3 shows the distribution of new high-growth establishments by industry. There are relatively higher portions of new high-growth establishments in wholesale trade, professional, scientific, and technical services, and construction. In contrast, transportation, finance and insurance, information, and manufacturing had lower proportions of high-growth establishments. Although manufacturing accounts for a relatively small portion of all high-growth establishments, the share of high-growth establishments in the total manufacturing industry is around 10 percent.

With respect to the age that new establishments first experienced high employment growth, the majority of them had their first high-growth experience within the first five years of their operation and 89 percent had their first high-growth experience within the first ten years of operation, as shown in Figure 2. Figure 3 shows the geographical distribution of new highgrowth establishments by county. They are highly concentrated in the Atlanta metro area. However, when represented as the percent of all new establishments, the new high-growth establishments are more dispersed across Georgia. 
Figure 2: Period of the First High-Growth Experience of New Establishments

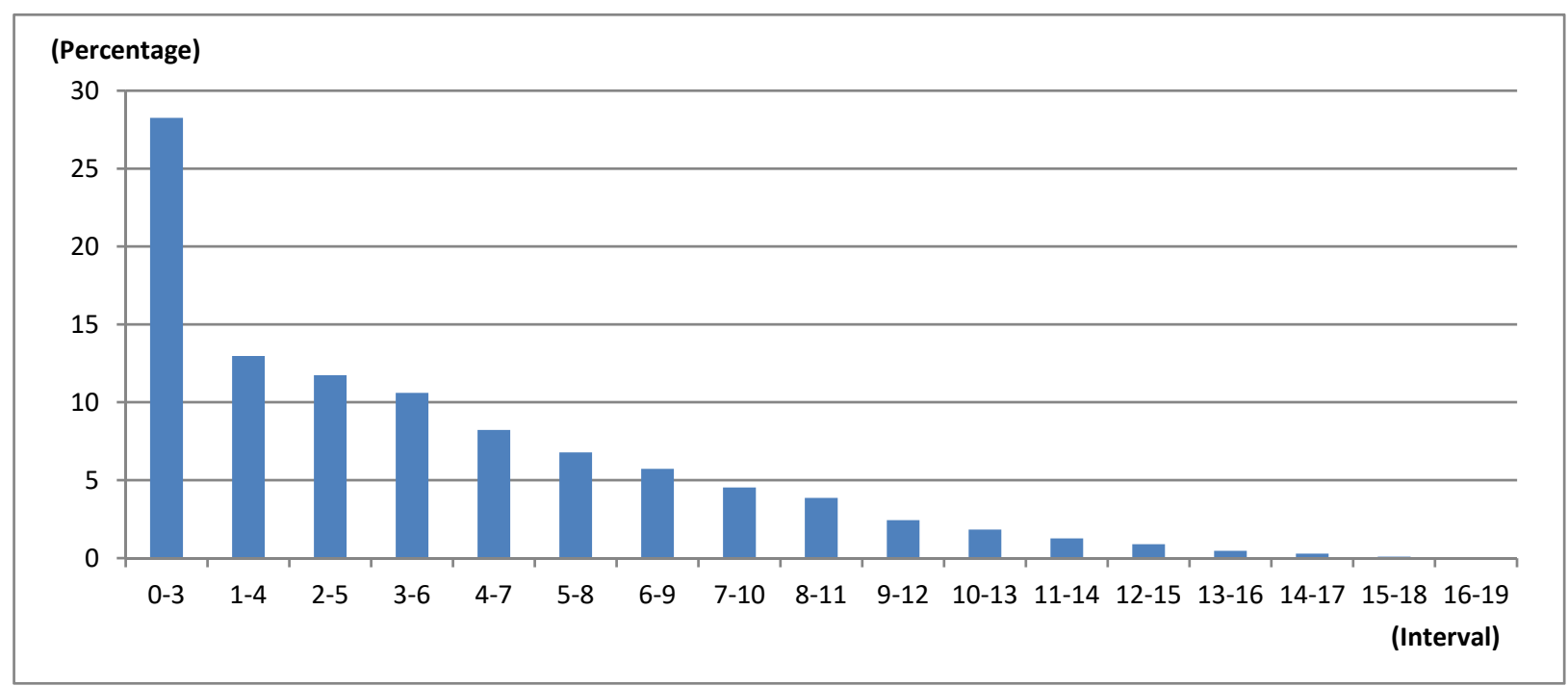

Source: NETS and authors' calculations

Figure 3: Spatial Distribution of High-Growth New Establishments by County in Georgia in the 1990s

High Growth New Establishment by County

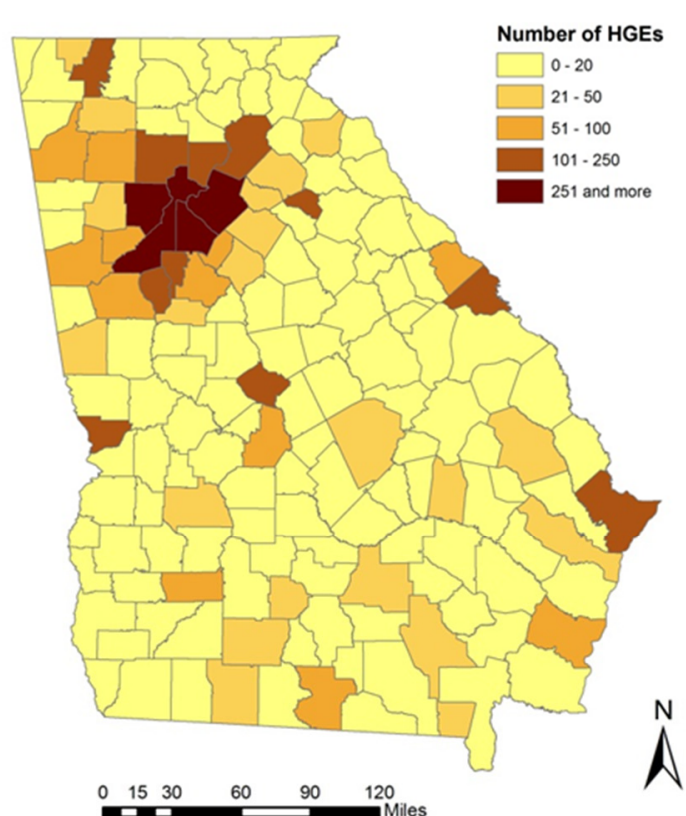

Percentage as High Growth New Establishments in All New Establishments

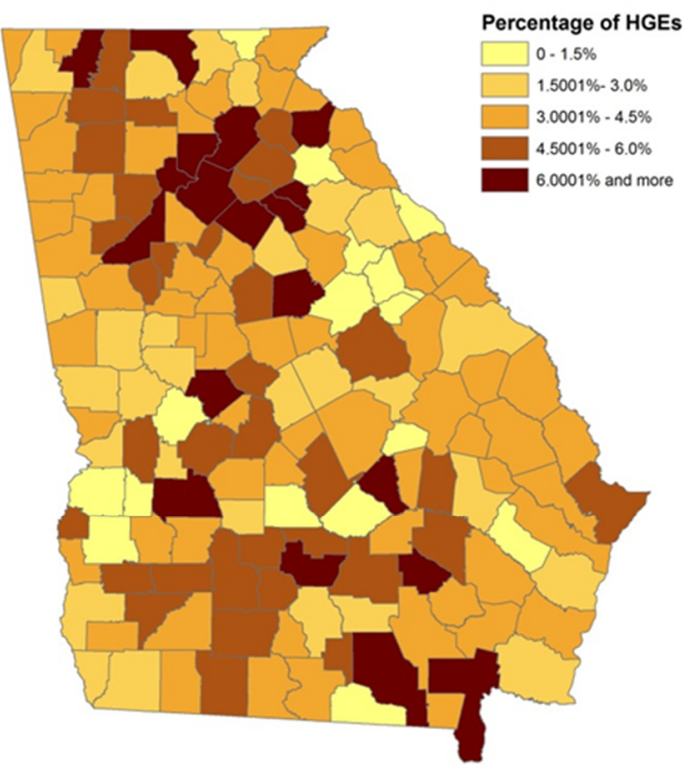

Source: NETS and authors' calculations

Previous research indicates that the employment change in high-growth firms is volatile and that high growth is often followed by zero growth or a setback (Storey, 2011). To shed some light on this issue, we examine changes in employment in the next eight years (two consecutive four-year periods) after the high-growth period. The data presented in Table 4 show that 
Table 4:Post-High Growth Trajectory

\begin{tabular}{|c|c|c|}
\hline Type & Frequency & Percentage \\
\hline Plateau & 873 & 25.6 \\
\hline Exit in the first 4 years & 847 & 24.9 \\
\hline Exit in 5 to 8 years & 454 & 13.3 \\
\hline Slow Growth & 371 & 10.9 \\
\hline Persistent High Growth & 170 & 5.0 \\
\hline Setback/Decline & 525 & 15.4 \\
\hline Volatile Change & 169 & 5.0 \\
\hline
\end{tabular}

Source: NETS and authors' calculations

Notes: The changes that occurred in employment in the first and the second four-year periods were considered separately as follows: high growth, slow growth (or less than high growth rate), no change, decline, and exit. More specifically: 1) if the employment level undergoes no change in both four-year time-periods, an establishment is allocated to the "Plateau" category.2) If an establishment exits in either the first or second four-year period, it is allocated to the "Exit" category.3) If a change in employment signals slow growth at least in one period, and no change in employment occurs in the other period, it is allocated to "Slow Growth" category. 4) If the change in employment indicates high growth at least in one period, and no change or slow growth occurs in another period, it is allocated to "Persistent High Growth" category. 5) If a change in employment declines at least in one period but no change occurs in another period, it is allocated to "Setback/Decline" category.6) Finally, if the change in employment indicates high growth in one period and a decline in another period, it is allocated to "Volatile Change" category.

persistent high growth is a rare event and that the probability of high-growth firms staying as high growth is very low, confirming findings in Daunfeldt and Halvarsson (2012). Table 4 also shows that zero growth, decline, or exit more frequently occurred in the post-high growth period. Only 16 percent maintained their growth momentum, suggesting that the effect of high growth may be limited for the survival of these firms in subsequent time periods.

Finally, we compare the survival and hazard rates between high growth and non-highgrowth establishments using the nonparametric Kaplan-Meier method; results are reported in Table 5. We calculated these rates for all new establishments, non-high-growth new establishments, and high-growth new establishments. The high-growth group includes only those that survived at least three years and experienced high growth, and therefore, for an accurate comparison, we also calculated the survival and hazard rates of non-high-growth establishments using establishments that survived at least three years. The calculations show that the survival and hazard rates between high-growth and non-high-growth establishments differ significantly. The survival rate of the former was 0.9472 after 5 years, 0.7830 after 10 years, and 0.6217 after 15 years. By contrast, the survival rate of non-high-growth establishments was 0.7842 after 5 years, 0.5547 after 10 years, and 0.3639 after 15 years. Similar results are notable for hazard rates between the two groups of establishments: the hazard rate tends to be higher for non-highgrowth establishments, compared to high-growth establishments. 
Table 5: Survival and Hazard Rate of New High-Growth Establishments

\begin{tabular}{|c|c|c|c|c|c|c|}
\hline \multirow[t]{2}{*}{ Interval } & \multicolumn{2}{|c|}{$\underline{\text { All Establishments }}$} & \multicolumn{2}{|c|}{$\begin{array}{c}\text { Establishments Surviving at } \\
\underline{\text { Least } 3 \text { Years }}\end{array}$} & \multicolumn{2}{|c|}{ High-Growth Establishments } \\
\hline & Survival Rate & Hazard Rate & Survival Rate & Hazard Rate & Survival Rate & Hazard Rate \\
\hline 12 & 0.8908 & 0.1155 & & & & \\
\hline 23 & 0.7443 & 0.1793 & & & & \\
\hline 34 & 0.6451 & 0.1427 & & & & \\
\hline 45 & 0.5655 & 0.1315 & 0.8681 & 0.1413 & 0.9770 & 0.0232 \\
\hline 56 & 0.5141 & 0.0952 & 0.7842 & 0.1016 & 0.9472 & 0.0310 \\
\hline 67 & 0.4736 & 0.0820 & 0.7188 & 0.0870 & 0.9153 & 0.0342 \\
\hline 78 & 0.4432 & 0.0664 & 0.6704 & 0.0696 & 0.8822 & 0.0368 \\
\hline 89 & 0.4174 & 0.0598 & 0.6298 & 0.0625 & 0.8510 & 0.0361 \\
\hline 910 & 0.3964 & 0.0518 & 0.5972 & 0.0532 & 0.8177 & 0.0399 \\
\hline 1011 & 0.3694 & 0.0705 & 0.5547 & 0.0738 & 0.7830 & 0.0433 \\
\hline 1112 & 0.3446 & 0.0694 & 0.5160 & 0.0721 & 0.7467 & 0.0474 \\
\hline 1213 & 0.3202 & 0.0733 & 0.4777 & 0.0772 & 0.7155 & 0.0428 \\
\hline 1314 & 0.2959 & 0.0788 & 0.4397 & 0.0830 & 0.6823 & 0.0475 \\
\hline 1415 & 0.2772 & 0.0654 & 0.4103 & 0.0692 & 0.6563 & 0.0389 \\
\hline 1516 & 0.2480 & 0.1110 & 0.3639 & 0.1197 & 0.6217 & 0.0541 \\
\hline 1617 & 0.2297 & 0.0768 & 0.3355 & 0.0814 & 0.5913 & 0.0501 \\
\hline 1718 & 0.2031 & 0.1229 & 0.2950 & 0.1284 & 0.5395 & 0.0917 \\
\hline 1819 & 0.1824 & 0.1077 & 0.2624 & 0.1168 & 0.5091 & 0.0579 \\
\hline 1920 & 0.1396 & 0.2657 & 0.1971 & 0.2841 & 0.4299 & 0.1688 \\
\hline
\end{tabular}

Source: NETS and Authors' Calculations

\section{MULTIVARIATE ANALYSIS}

Our main interest lies in the analysis of the effects of high growth on the duration or survival rate of all new and new high-growth establishments in Georgia. We calculate the duration using the length of time that passes from the birth of a particular establishment until it exits or until the end of period considered. The variable observed here is the number of years an establishment has survived but for the establishments that continue to survive after our time period, this number will be the minimum number of years an establishment has survived. The censored nature of survival data is unavoidable in duration analysis (Greene, 2000). It also leads to an important question: if an establishment has survived until a particular point in time, then what is the probability that it will exit in the next short interval of time (Greene, 2000)? The econometric literature defines this aspect of the probability function of survival as the hazard rate. Essentially, the hazard rate is the conditional probability that if an establishment survives to a particular time $t$, it will exit in the next short interval of time $(\Delta t)$, or in the next year for this study.

We will use duration analysis employing the hazard model to investigate the determinants of new firm exit (or more specifically firm survival). This framework allows us to quantify the timing of the exit, rather than the mere incidence. The application of a hazard model (Cox, 1972) for the likelihood of firm survival has become a routine method used in the empirical literature (Audretsch and Mahmood,1995; Musso and Schiavo 2008; Christie and Sjoquist, 2012).

(C) Southern Regional Science Association 2017. 
Following the standard notation of survival analysis models, let $T$ denote the duration of time that a firm has been in existence and $t$ as the current time. The probability that a given firm fails or ceases operations within a short interval of time, $(t, t+d t)$, conditional on the fact that it has not failed as of period $t$, can be calculated as follows:

$$
h i(t \mid X)=\lim _{d t \rightarrow 0} \frac{P(t \leq T \leq t+d t \mid T \geq t ; X i)}{d t}
$$

where $X$ is the vector of covariates that are likely to affect the duration of the firm's existence. Empirically, to examine the effects of covariates on duration, researchers have used a proportional hazards model (Cox, 1972) which assumes that the hazard rate is a multiplicative function of a baseline hazard, $h_{0}(t)$, and an exponential function of a set of covariates:

$$
h i(t \mid X)=\mathrm{h}_{0}(\mathrm{t}) \exp \left(\mathrm{X}_{\mathrm{i}} \beta\right)
$$

where $\beta$ represents the vector of coefficients and $X_{i}$ is a vector of explanatory variables. We employ a discrete-time hazard model because of the discrete nature of the NETS data in which the time unit is a year. When survival times are continuous, but they are measured by a discrete interval time such as a month or year, the complementary log-log specification is an appropriate discrete-time hazard model (Jenkins, 2005). Still, there is sample selection bias in our data that needs to be taken into consideration in the estimation of the model. Since the determination of high growth requires a minimum three-year period, we excluded new establishments that exited during the first three years from our sample. This approach may create a bias in coefficient estimates and, therefore, the estimation technique needs to be analogous to Heckman's (1979) two-step sample selection model. Heckman's original two-step technique is designed for continuous dependent variables estimated by linear regression in the second stage. In the present case, our dependent variable in the second stage is also a binary choice variable. Fortunately, the technique has been adapted for discrete dependent variables where both the selection equation and the outcome equation are binary choices (van de Venn and Van Praag 1981). Following Dimico (2013), we use a Maximum Likelihood Heckman-Probit Model estimation technique commonly known as heckprobit in the Stata econometric software package. ${ }^{8}$

The duration of a new establishment is measured by the length of years from the first to last appearance in the NETS. Since the NETS data tracks information associated with the headquarters and ownership of individual establishments, we were able to track changes in ownership. In this analysis, the duration of establishment includes all periods in operation regardless of changes in ownership.

\subsection{Variables}

To investigate our research questions, we divide our sample of new establishments into three separate categories. One is the full sample that includes all new establishments in the study period. Two sub-samples are new high-growth firms and new non-high-growth firms. Table 6 presents the explanatory variables included in the model that are hypothesized to influence the survival of new establishments in Georgia and are classified into three groups: establishment-, industry-, and location-specific characteristics.

Our primary interest in the paper is to analyze the impact of initial high employment growth on the survival of new establishments. We use several aspects of employment growth in

${ }^{8}$ Dimico (2013) uses the Heckman probit estimator in the context of discrete-time, duration models.

(C) Southern Regional Science Association 2017. 
Table 6: Descriptive Summary of Variables

\begin{tabular}{|c|c|c|c|c|c|c|c|c|}
\hline Group & Variables & $\begin{array}{c}\text { Level of } \\
\text { Measurement }\end{array}$ & Observations & Mean & S.D & Min & Max & $\begin{array}{l}\text { Expected } \\
\text { Sign }\end{array}$ \\
\hline \multirow[t]{8}{*}{ Establishment } & Duration & Establishment & 106,379 & 10.469 & 4.393 & 4 & 19 & \\
\hline & Exit & Establishment & 106,379 & 0.574 & 0.495 & 0 & 1 & \\
\hline & Initial Size & Establishment & 106,379 & 14.395 & 62.564 & 3 & 4,500 & \\
\hline & Current-Size & $\begin{array}{l}\text { Establishment } \\
\text { (Time-varying) }\end{array}$ & 786,110 & 15.563 & 55.748 & 1 & 4,000 & - \\
\hline & $\begin{array}{l}\text { Employment } \\
\text { Growth Rate }\end{array}$ & $\begin{array}{l}\text { Establishment(Time- } \\
\text { varying) }\end{array}$ & 786,110 & 0.071 & 0.581 & -1.000 & 10 & - \\
\hline & $\begin{array}{l}\text { Dummy for High } \\
\text { Growth at the } \\
\text { First Three Years }\end{array}$ & $\begin{array}{l}\text { Establishment(Time- } \\
\text { invariant) }\end{array}$ & 106,379 & 0.024 & 0.153 & 0 & 1 & - \\
\hline & $\begin{array}{l}\text { Dummy for } \\
\text { Multi- } \\
\text { Establishment } \\
\text { Firm at } \\
\text { Beginning Year }\end{array}$ & $\begin{array}{l}\text { Establishment; } \\
\text { (Time-invariant) }\end{array}$ & 106,379 & 0.223 & 0.417 & 0 & 1 & - \\
\hline & $\begin{array}{l}\text { Dummy for } \\
\text { Ownership } \\
\text { Change }\end{array}$ & $\begin{array}{l}\text { Establishment; } \\
\text { (Time-invariant) }\end{array}$ & 106,379 & 0.106 & 0.308 & 0 & 1 & - \\
\hline \multirow[t]{2}{*}{ Industry } & $\begin{array}{l}\text { Industry Growth } \\
\text { Rate }\end{array}$ & $\begin{array}{l}\text { Industry } \\
\text { (Annual) }\end{array}$ & 437 & 0.014 & 0.077 & -0.559 & 0.329 & - \\
\hline & $\begin{array}{l}\text { Establishment } \\
\text { Growth Rate }\end{array}$ & $\begin{array}{l}\text { Industry } \\
\text { (Annual) }\end{array}$ & 437 & 0.096 & 0.062 & 0.015 & 0.402 & + \\
\hline \multirow[t]{4}{*}{ Location } & $\begin{array}{l}\text { Population } \\
\text { Growth Rate }\end{array}$ & $\begin{array}{l}\text { County } \\
\text { (Annual) }\end{array}$ & 3,021 & 0.016 & 0.020 & -0.161 & 0.143 & - \\
\hline & $\begin{array}{l}\text { Location } \\
\text { Quotient }\end{array}$ & $\begin{array}{l}\text { County \& Industry } \\
\text { (Annual) }\end{array}$ & 66,804 & 1.398 & 5.481 & 0.003 & 269.367 & - \\
\hline & $\begin{array}{l}\text { Labor Force } \\
\text { Density }\end{array}$ & $\begin{array}{l}\text { County } \\
\text { (Annual) }\end{array}$ & 3,021 & 83 & 180 & 2 & 1471 & $+/-$ \\
\hline & Diversity & $\begin{array}{l}\text { County } \\
\text { (Annual) }\end{array}$ & 3,021 & 2.461 & 0.334 & 0.000 & 2.921 & - \\
\hline
\end{tabular}

order to accomplish this task. First, to examine how the hazard rate varies over employment growth rates, we include a time-variant variable of the employment growth rate in the past three years. Second, since we expect a U-shaped relationship between employment growth and hazard rates, we include a squared term of the employment growth rate. Third, we use a dummy variable for high employment growth during the first three years, based on our high growth definition discussed above. The entrants may suffer from a size disadvantage when their output level falls below the minimum efficient scale. Entrants experiencing fast growth in early years and reaching a minimum efficient size are able to survive longer. Hence, we expect that if new entrants grow rapidly during the early-year period, a risk of failure in the rest of the life cycle of new establishments significantly declines. Fourth, we include the current employment size of the establishment and following previous literature, hypothesize it to be inversely related to hazard rate. We also include a squared-term of this variable to gauge nonlinear effects.

To control for other establishment-level effects, we include organizational structure and ownership change. The organizational structure of an establishment can be an influential factor. 
If a new entrant is a part of a multi-establishment firm, it is usually better informed about the market conditions and efficient entry size, and may have better access to financial assets, so that new establishments of multi-establishment organization confronts a lower risk of failure, especially in the early years of its life cycle. ${ }^{9}$ The changes in ownership also can matter in business survival. For example, a merger may indicate success of a new establishment, and then it would be positively associated with the survival of a new establishment.

With respect to industry-specific variables, following Christie and Sjoquist (2012), we include the annual industry growth rate and industry entry rate. If an establishment starts in an expanding industry sector, we expect that its survival rate will increase. Since the industry entry rate represents the intensity of competition, we expect this measure to be positively associated with the hazard rate, indicating high entry rate will decrease firm survival in a particular industry. The industry growth rate and industry entry rates are measured at a two-digit industry level of the North American Industry Classification System (NAICS). The industry entry rate is calculated as a portion of the number of entrants in the total number of establishments in the same sector.

Finally, we take into account local economic conditions. Since entrants with limited financial and human resources are commonly connected with local suppliers and serve the local market, entry and survival rates will vary from place to place, each with its unique demographic, physical, and economic conditions. Many high-growth establishments produce nontradable products such as construction, health care, wholesale, and retail services, as shown in Table 3, and presumably their growth and survival heavily relies on local demand. We include four county-specific variables: location quotients, labor-force density, population growth, and industry diversity.

The location quotient quantifies how concentrated a particular industry in a locality is, compared to a larger geographic area. Location quotients are computed at the two-digit industry level for a county, and the reference region is the State of Georgia. We expect that the location quotient will have a positive effect on the survival of an establishment (and a negative effect on the hazard rate). The second variable, labor-force density, represents the effect of urbanization. It reflects not only such benefits as better access to a differentiated labor market, the availability of specialized service suppliers, and proximity to a market with demand, but also the diseconomies of dense areas such as congestion, excessive competition, and higher land prices. Previous research has identified mixed effects of urbanization on survival rates: While some studies find a positive impact (Wennberg and Lindqvist, 2010; Fotopoulos and Louri, 2000) other studies show a higher risk of failure of new establishments located in high-density areas (Christie and Sjoquist, 2012; Fritsch, Brixy, and Falck, 2006). The third variable is the county population growth rate, which represents the expansion or contraction of local demand. We hypothesize that the population growth rate will be positively associated with the survival rate. Finally, we use Shannon's entropy index as a measure of industry diversity, which is maximal if county employment is equally distributed across all industries, and equal to zero if county employment is concentrated in only one industry (Attaran, 1986). We expect diversity to positively affect the survival rate (Renski, 2012).

\footnotetext{
${ }^{9}$ In our sample, 22.3 percent of new establishments are part of multi-establishment firms. The new entrants which are part of multi-establishment firms tend to start with a greater number of employees rather than single-establishments. Indeed, about threefourths of new establishments with over 100 employees at incipience are part of multi-establishment firms.
}

(C) Southern Regional Science Association 2017. 


\section{$5.2 \quad$ Results}

Through the survival analysis, we test hypotheses pertaining to the effect of high employment growth of a new establishment on the likelihood of its survival. Since the determination of high growth requires a minimum three-year period, we excluded new establishments that exited during the first three years. Because we arbitrarily select a sample of firms that grew in the first three years, ignoring the new firms that exited at the first three years of inception, our sample is subject to estimation bias. To correct this bias, we use a Heckman sample-selection correction procedure using Heckman probit estimation. ${ }^{10}$ Results are presented for both selection and outcome equations. For the sake of conciseness, we only discuss the results from the outcome equation which is the primary focus of the paper. Since the likelihood ratio (LR) test of independence of equations was statistically significant in all specifications, the results without this correction may be biased and are not reported. As mentioned above, we estimate three specifications from a sample of new establishments that had survived at least three years: (1) all new establishments (model 1); all new high-growth establishments (model 2); and all new non-high-growth establishments (model 3).

Table 7 presents the discrete hazard model results with Heckman correction for all new establishments. Two specifications of model 1 are estimated to avoid collinearity issues. ${ }^{11}$ The first specification includes employment growth and its squared term and the second specification includes a dummy variable for high-growth establishments in the first three years.

As hypothesized above, the employment growth of a new establishment is a significant determinant of its survival. The estimated coefficient is statistically significant and negative, indicating that employment growth reduces the hazard rate for new establishments. We also find that this relationship is nonlinear. A U-shaped relationship between employment growth and the hazard rate indicates that the effect of continuous high employment growth is unfavorable for business survival after a point. Figure 4 shows the predicted hazard rates and a quadratic fitted line for employment growth rates. The hazard rate increases approximately beyond 400 percent employment growth rate over three years. Further examination of our sample shows that there were only few cases that have extremely high employment growth rates (over 400 percent employment growth rate), and they are mostly small-size establishments with less than 20 employees. ${ }^{12}$ Therefore, the U-shaped relationship between hazard rate and employment growth may be attributed to small-sized establishments with extremely high growth rates. ${ }^{13}$

\footnotetext{
${ }^{10}$ Since we include regional factors as covariates, it is possible that these factors may also be spatially correlated. Therefore, one should test for the existence of such spatial relationships and use spatial modeling techniques to correct for spatial dependence if they exist. Due to practical difficulty in implementing such tests in the context of a Heckman probit model, however, we were unable to test for spatial effects. We admit that our results may be subject to bias due to this shortcoming.

${ }^{11} \mathrm{We}$ have tested the data for collinearity and found that this is not excessive in the present set of variables. The average variance inflation factor (VIF) is 1.33 .

${ }^{12}$ To explore this issue further, we ran the model excluding cases with an employment growth rate over 400 percent. The results are not reported here for the sake of brevity but they show that the estimated coefficient of the employment growth rate squared is not statistically significant in this specification. This confirms that the cases with extremely high growth rate firms in our data contribute to a nonlinear relationship between employment growth rate and the hazard rate. The estimate for current size squared is still significant, emphasizing the importance of current extreme high growth and business survival.

${ }^{13}$ Fast growth is not always associated with a reduction in the risk of failure. In some cases, fast-growing firms may experience financial and managerial problems stemming from the abrupt expansion of their organization, so that some fast growing small firms may end with sudden failure. Our empirical results appear to reflect the possibility that smaller firms are less likely to manage those risks. Some literature addressed this issue in part (Storey, 2011; Mohr and Gansey, 2011).
} 
Table 7: Determinants of Hazard Rates of New Establishments

\begin{tabular}{|c|c|c|c|c|}
\hline \multirow[b]{2}{*}{ Variables } & \multicolumn{4}{|c|}{ Probit Model with Heckman Correction (Model 1) } \\
\hline & Coefficient & Std. Err. & Coefficient & Std. Err. \\
\hline \multicolumn{5}{|l|}{ Outcome Equation: Failure or not } \\
\hline Employment Growth Rate & $-0.1254 * * *$ & 0.0063 & & \\
\hline Employment Growth Rate Sq. & $0.0151 * * *$ & 0.0011 & & \\
\hline High growth in the First Three Years & & & $-0.0695^{* * *}$ & 0.0134 \\
\hline Current Size & $-0.0007 * * *$ & 0.0001 & $-0.0004 * * *$ & 0.0000 \\
\hline Current Size Sq. & $0.0000 * * *$ & 0.0000 & $0.0000 * * *$ & 0.0000 \\
\hline Age & $-0.0338 * * *$ & 0.0006 & $-0.0337 * * *$ & 0.0006 \\
\hline Multi-establishment firm in the beginning year & $-0.0293^{* * *}$ & 0.0050 & $-0.0334 * * *$ & 0.0049 \\
\hline Ownership Change & $-0.0858^{* * *}$ & 0.0067 & $-0.0888^{* * *}$ & 0.0067 \\
\hline Industry Growth Rate & $-3.1139^{* * *}$ & 0.0369 & $-3.1181 * * *$ & 0.0365 \\
\hline Establishment Entry Rate & $-1.5908^{* * *}$ & 0.0325 & $-1.6022^{* * *}$ & 0.0322 \\
\hline Population Growth Rate & $-2.9885^{* * *}$ & 0.1111 & $-3.0367 * * *$ & 0.1105 \\
\hline Location Quotient & $-0.0084^{* * *}$ & 0.0017 & $-0.0091^{* * *}$ & 0.0017 \\
\hline Labor Force Density & $0.0002 * * *$ & 0.0000 & $0.0002 * * *$ & 0.0000 \\
\hline Diversity & $-0.4226^{* * *}$ & 0.0032 & $-0.4231 * * *$ & 0.0032 \\
\hline $\begin{array}{l}\text { Number of Establishments } \\
\text { Log-Likelihood }\end{array}$ & $\begin{array}{r}794,465 \\
-900,255 \\
\end{array}$ & & $\begin{array}{r}794,465 \\
-905,222 \\
\end{array}$ & \\
\hline \multicolumn{5}{|l|}{ Selection Equation: Survival at least three } \\
\hline Initial Size of Establishment & $0.0001 * * *$ & 0.0000 & $0.0001 * * *$ & 0.0000 \\
\hline Multi-establishment at the Beginning year & $0.0541 * * *$ & 0.0031 & $0.0591 * * *$ & 0.0031 \\
\hline Ownership Change & $0.2157 * * *$ & 0.0042 & $0.2253 * * *$ & 0.0042 \\
\hline Industry Growth Rate & $-7.2718^{* * *}$ & 0.0234 & $-7.2519 * * *$ & 0.0234 \\
\hline Establishment Entry Rate & $-5.6011^{* * *}$ & 0.0188 & $-5.5927 * * *$ & 0.0188 \\
\hline Population Growth Rate & $-8.3328^{* * *}$ & 0.0671 & $-8.3420 * * *$ & 0.0669 \\
\hline Location Quotient & $-0.0117 * * *$ & 0.0010 & $-0.0099 * * *$ & 0.0010 \\
\hline Labor Force Density & $0.0000 * * *$ & 0.0000 & $0.0000 * * *$ & 0.0000 \\
\hline Diversity & $0.4166^{* * *}$ & 0.0086 & $0.4183^{* * *}$ & 0.0086 \\
\hline ( & 0.7554 & 0.0166 & 0.7589 & 0.0167 \\
\hline LR Test of Independent Equations (Chi2) & $1119.39 * * *$ & & $113.5 .21 * * *$ & \\
\hline
\end{tabular}




\section{Figure 4: Predicted Hazard Rate across Employment Growth Rates}

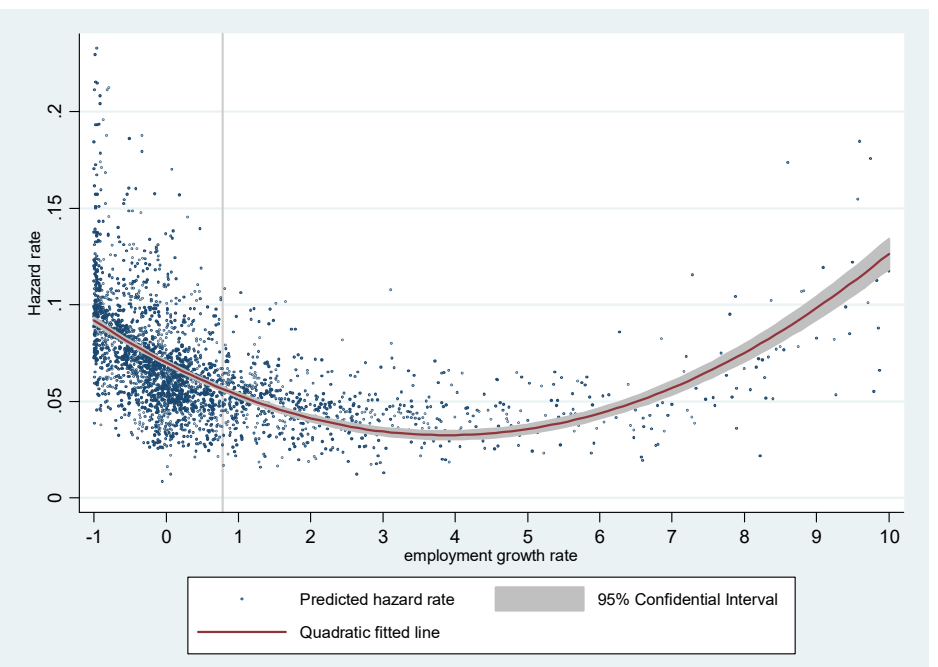

Note: Predicted hazard rates are drawn from Model 1 in Table 7 with actual observed values of all explanatory variables. The gray vertical line indicates the high employment growth criterion; i.e., 72.8 percent or greater growth rate over a three-year period.

To test the hypothesis that high-growth establishment status may be associated with new establishment survival, we estimate the second specification. These results are reported in Table 7. The results show that high growth status reduced the hazard rate of young establishments. The dummy variable for high-growth establishments in the first three years produced a negative sign on the hazard rate, and is statistically significant.

With respect to the effect of establishment size, we confirm the findings of previous studies that the current size of an establishment has a significant effect on reducing the hazard rate, suggesting that the current size is indeed an important factor in explaining the survival of new establishments. It is worth noting that even after controlling for size, we still find an effect of employment growth on survival: that is, the fact that a firm's employment growth is a powerful contributor to the probability of survival. Nonetheless, similar to the employment growth effect discussed above, the effect of employment size on the hazard rate is also nonlinear. The coefficient of the squared term of the size variable is significant and positive. Results with respect to the establishment age variable confirm the general finding in the firm survival literature that the probability that a business will fail decreases with age.

Estimated coefficients of the variables that measure organizational structure and ownership change were significant determinants of the hazard rate of new establishments. Results show that the hazard rate of a new establishment that was part of a multi-establishment firm upon entry was lower than that of a single-establishment firm. This confirms the findings in Christie and Sjoquist (2012) that a new firm with multiple establishments would be expected to have a better chance of survival. In addition, a new establishment that experienced a change in ownership faced a lower hazard rate.

Regarding the effects of industry variables: consistent with our expectation, young establishments in expanding industries experienced a lower risk of failure. This measure is not statistically significant in Christie and Sjoquist (2012) and the reason for conflicting findings is 
unclear. ${ }^{14}$ Contrary to our expectations and the finding in Christie and Sjoquist (2012), the new establishment entry rate in an industry or the competition measure is negatively associated with the hazard rate of new establishments, indicating that intense competition is actually better for business survival. Again, the reason for the difference in results between our analysis and Christie and Sjoquist (2012) is unclear.

All the county-level characteristics that we include in the model are statistically significant. The estimated coefficient of the labor force density indicates a negative effect on the survival of new establishments, implying that new businesses located in populated areas such as the Atlanta metropolitan area confronted a higher risk of failure. This finding is consistent with Christie and Sjoquist (2012). While we conjecture that this result is attributed to the intensive competition and diseconomies inherent in metropolitan areas, the exact mechanism through which factors create unfavorable environments to firm survival in a populated area remains unclear. We also find that the hazard rate decreases with industry diversity; that is, a new establishment located in a more diversified area is more likely to survive. The high concentration of an industry in a county with respect to the state, measured by the location quotient, has a positive effect on business survival, indicating businesses that gain benefits from being part of a regionally specialized industry cluster survive longer. Population growth significantly reduces the hazard rate, implying that the survival of new establishments in high population growth counties may be partly due to increase in local demand.

In a second set of estimations, we compare the determinants of the survival of new highgrowth with non-high-growth establishments using the same set of factors except the highgrowth status variable. Table 8 shows that the analysis of high-growth establishments produces some outcomes that are inconsistent with our expected signs while the relationship displayed in analysis of all establishments largely hold for the non-high-growth sample. ${ }^{15}$

In the high-growth establishment regression, both employment growth and its squared term are not statistically significant. This implies that when a new high-growth establishment grows at a certain pace, its risk of failure does not depend on the prior variation in employment growth rates. Even though the argument that firms growing too fast at an early age may be prone to failure generally holds for new businesses, it does not hold in the case specific of high-growth firms. The size variable is still statistically significant, which confirms its nonlinear relationship with business survival. This further runs against Gibrat's Law, which states firm growth is independent of its size. Another unexpected result in the high-growth sample is that multiestablishment firms have lower survival rates. Interpretation of this result is difficult. One possible explanation is that the advantage of small, fast-growing, single establishments can offset the benefits gained from large multi-establishment organizations. The results also show that the location quotient was not statistically significant in the survival of high-growth establishments, implying that the survival patterns of new high-growth establishments may depend less on local industry characteristics. One point to note is that the effect of the employment-growth results in the sample with all new establishments may be driven by its non-high-growth subsample. The negative coefficient of the employment growth rate in the non-high-growth model is slightly

\footnotetext{
${ }^{14}$ Note two studies examined the hazard rates of new establishment in the State of Georgia, but differ in terms of the data sets used for analysis, the estimations methods (Christie and Sjoquist, 2012, use a Cox proportional hazard model), and the selection of the period of study for new establishments.

${ }^{15}$ Since the results of the non-high-growth regression are almost identical to those of the all new business sample, we do not discuss them here for the sake of conciseness.
}

(c) Southern Regional Science Association 2017. 
Table 8: Comparison of Determinants of Hazard Rates for New High-Growth and Non-High-Growth Establishments

\begin{tabular}{|c|c|c|c|c|}
\hline \multirow[b]{2}{*}{ Variables } & \multicolumn{2}{|c|}{$\begin{array}{l}\text { New high-growth establishments in } \\
\text { the first three years (Model 2) }\end{array}$} & \multicolumn{2}{|c|}{$\begin{array}{c}\text { New non-high-growth } \\
\text { establishments (Model 3) }\end{array}$} \\
\hline & Coefficient & Std. Err. & Coefficient & Std. Err. \\
\hline \multicolumn{5}{|l|}{ Outcome Equation: Failure or not } \\
\hline Employment Growth Rate & 0.0158 & 0.0222 & $-0.1353 * * *$ & 0.0068 \\
\hline Employment Growth Rate Sq. & 0.0013 & 0.0031 & $0.0152 * * *$ & 0.0012 \\
\hline Current Size & $-0.0010 * *$ & 0.0004 & $-0.0007 * * *$ & 0.0001 \\
\hline Current Size Sq. & $0.0000^{*}$ & 0.0000 & $0.0000 * * *$ & 0.0000 \\
\hline Age & -0.0088 & 0.0057 & $-0.0338 * * *$ & 0.0006 \\
\hline Multi-establishment at the Beginning year & $0.0989 * * *$ & 0.0326 & $-0.0316^{* * *}$ & 0.0050 \\
\hline Ownership Change & -0.0572 & 0.0393 & $-0.0847 * * *$ & 0.0069 \\
\hline Industry Growth Rate & $-2.6321 * * *$ & 0.2936 & $-3.1226 * * *$ & 0.0372 \\
\hline Establishment Entry Rate & $-0.7568 * * *$ & 0.2589 & $-1.6074 * * *$ & 0.0328 \\
\hline Population Growth Rate & $-2.7922 * * *$ & 0.8205 & $-2.9919 * * *$ & 0.1121 \\
\hline Location Quotient & 0.0043 & 0.0168 & $-0.0085 * * *$ & 0.0017 \\
\hline Labor Force Density & $0.0002 * * *$ & 0.0000 & $0.0002 * * *$ & 0.0000 \\
\hline Diversity & $-0.5875 * * *$ & 0.0281 & $-0.4212 * * *$ & 0.0032 \\
\hline Number of Establishments & 17,624 & & 768,373 & \\
\hline \multicolumn{5}{|l|}{ Selection Equation: Survival at least three } \\
\hline \multicolumn{5}{|l|}{ years or not } \\
\hline Initial Size of Establishment & $0.0014 * * *$ & 0.0004 & $0.0001 * * *$ & 0.0000 \\
\hline Multi-establishment at the Beginning year & $-0.1185^{* * *}$ & 0.0205 & $0.0570 * * *$ & 0.0032 \\
\hline Ownership Change & -0.0046 & 0.0236 & $0.2214 * * *$ & 0.0043 \\
\hline Industry Growth Rate & $-8.2612 * * *$ & 0.1708 & $-7.2502 * * *$ & 0.0237 \\
\hline Establishment Entry Rate & $-6.0018 * * *$ & 0.1447 & $-5.5913 * * *$ & 0.0190 \\
\hline Population Growth Rate & $-7.3737 * * *$ & 0.4868 & $-8.3540 * * *$ & 0.0678 \\
\hline Location Quotient & $-0.0292 * *$ & 0.0116 & $-0.0115 * * *$ & 0.0011 \\
\hline Labor Force Density & $0.0001 * * *$ & 0.0000 & $0.0000 * * *$ & 0.0000 \\
\hline Diversity & $0.3171 * * *$ & 0.0716 & $0.4183 * * *$ & 0.0087 \\
\hline rho & 0.6707 & 0.1340 & 0.7569 & 0.0168 \\
\hline LR Test of Independent Equations (Chi2) & 19.76 & & 1092.30 & \\
\hline
\end{tabular}

larger than that for all new establishments. This further indicates that slow-growing or nongrowing businesses can increase their survival chances by growing.

\section{CONCLUSION}

This study examined the survival pattern of young establishments including those of high-growth in the State of Georgia within the Unites States. In particular, we analyzed how high employment growth affects the survival rate of all new establishments and new high-growth 
establishments. Our primary finding is that young establishments that have experienced high growth early in their life cycle are more likely to survive than those that have not. High growth experience has a positive impact on establishment survival in a current and post-high growth period. One shortcoming of the paper is that we only had access to data for the State of Georgia. This makes it difficult to generalize findings to a broader context, like to the nation or even just the U.S. South.

The analysis provided some insights into entrepreneurial development policy related to fostering high-growth firms. A general policy implication is that because high employment growth is positively associated with business survival, new start-ups may benefit from a policy environment that enables them to "take-off" from the very beginning. Our results are consistent across all subsamples that we investigated (all new establishments, high-growth, and lowgrowth). This suggests that support for all start-ups could facilitate survival, at least in Georgia.

As we more deeply probed serial growth patterns, however, we found that high growth was often erratic and that persistent high growth was extremely rare. Most high-growth establishments do not represent the ideal image of a long-run growth business. Our descriptive analysis of such establishments implies that young firms that rapidly expanded in one period often suffer a substantial loss in the following period; thus, they can be temporally vulnerable to an elevated risk of failure. In addition, the list of young high-growth firms can completely change from one period to the next. Thus, heterogeneous serial growth patterns of young firms affect survival probabilities. Finally, the definition of "high growth" is somewhat arbitrary and certainly biased towards fast-growing smaller firms. Hence, it is likely that, in sum, very small high-growth firms do not contribute more to the local economy than do larger non-high-growth firms that employ a similar number of workers. ${ }^{16}$

\section{REFERENCES}

Acs, Zoltan and Catherine Armington. (2004) "Employment Growth and Entrepreneurial Activity in Cities," Regional Studies, 38, 911-927.

Acs, Zoltan J. (2011) "High-impact Firms: Gazelles Revisited," in Michael Fritsch (ed.), Handbook of Research on Entrepreneurship and Regional Development. Edward Elgar Publishing: Cheltenham, UK.

Agarwal, Rajshree and David B. Audretsch. (2001) "Does Entry Size Matter? The Impact of the Life Cycle and Technology on Firm Survival," Journal of Industrial Economics, 49, 2143.

Allison, Paul D. (1982) "Discrete-time Methods for the Analysis of Event Histories," Sociological Methodology, 13, 61-98.

Attaran, Mohsen. (1986) "Industrial Diversity and Economic Performance in US Areas," Annals of Regional Science, 20, 44-54.

Audretsch, David B. and TalatMahmood. (1995) "New Firm Survival: New Results Using a Hazard Function," Review of Economics and Statistics, 77, 97-103.

Choi, Taelim, John Robertson, and Anil Rupasingha. (2013) "High-growth Firms in Georgia."Federal Reserve Bank of Atlanta Working Paper No. 2013-20: Atlanta, GA.

\footnotetext{
${ }^{16} \mathrm{We}$ are grateful to an anonymous reviewer for this point.
}

(C) Southern Regional Science Association 2017. 
Christie, Tamoya and David L. Sjoquist. (2012) "New Business Survival in Georgia: Exploring the Determinants of Survival Using Regional Level Data," Growth and Change, 43, 110142.

Clayton, Richard L., Akbar Sadeghi, James R. Spletzer, and David M. Talan. (2013) "Highemployment-growth Firms: Defining and Counting Them," Monthly Labor Review, 136, $3-13$.

Coad, Alex. (2007) “A Closer Look at Serial Growth Rate Correlation," Review of Industrial Organization, 31, 69-82.

Cox, David R. (1972) "Regression Models and Life Tables," Journal of the Royal Statistical Society, 34, 187-220.

Daunfeldt, Sven-Olov, NiklasElert, and Dan Johansson. (2010) "The Economic Contribution of High-Growth Firms: Do Definitions Matter?" Ratio Institute Working Paper151: Stockholm, Sweden.

Daunfeldt, Sven-Olov and Daniel Halvarsson. (2015) "Are High-growth Firms One-hit Wonders? Evidence from Sweden," Small Business Economics, 44, 361-383.

Davis, Steven J., John Haltiwanger, and Scott Schuh. (1996) "Small Business and Job Creation: Dissecting the Myth and Reassessing the Facts," Small Business Economics, 8, 297-315.

Delmar, Frédéric, Per Davidsson, and William B. Gartner. (2003) "Arriving at the High-growth Firm,” Journal of Business Venturing, 18, 189-216.

Dimico, Arcangelo. (2013) "The Evolution of Conflict and Effectiveness of Aid." Munich Personal RePEc ArchiveNo.47050: Munich.

Dunne, Paul and Alan Hughes. (1994) “Age, Size, Growth and Survival: UK Companies in the 1980s," Journal of Industrial Economics, 42,115-140.

Dunne, Timothy, Mark J. Roberts, and Larry Samuelson. (1989) “The Growth and Failure of US Manufacturing Plants," Quarterly Journal of Economics,104, 671-698.

Evans, David S. (1987) “The Relationship between Firm Growth, Size, and Age: Estimates for 100 Manufacturing Industries," Journal of Industrial Economics, 34, 567-581.

Eurostat OECD (2007) Eurostat-OECD Manual on Business Demography Statistics, OECD, Paris.

Farinas, Jose C. and Lourdes Moreno. (2000) 'Firms' Growth, Size and Age: A Nonparametric Approach," Review of Industrial Organization, 17, 249-265.

Fritsch, Michael and Pamela Mueller. (2004) "Effects of New Business Formation on Regional Development Over Time," Regional Studies, 38, 961-975.

Fritsch, Michael, UdoBrixy, and Oliver Falck. (2006) "The Effect of Industry, Region, and Time on New Business Survival- AMulti-dimensional Analysis," Review of Industrial Organization, 28, 285-306.

Fotopoulos, Georgios and Helen Louri. (2000) "Location and Survival of New Entry," Small Business Economics, 14, 311-321.

(C) Southern Regional Science Association 2017. 
Geroski, Paul A. (1995) "What Do We Know About Entry?," International Journal of Industrial Organization, 13, 421-440.

Goetz, Stephan J. and Anil Rupasingha. (2009) "Determinants of Growth in Non-farm Proprietor Densities in the US, 1990-2000." Small Business Economics, 32, 425-438.

Greene, William H. (2000)Econometric Analysis, International edition.

Haltiwanger, John, Ron S. Jarmin, and Javier Miranda. (2013) "Who Creates Jobs? Small Versus Large Versus Young," Review of Economics and Statistics, 95, 347-361.

Henrekson, Magnus and Dan Johansson. (2010) "Gazelles as Job Creators: A Survey and Interpretation of the Evidence," Small Business Economics, 35, 227-244.

Jenkins, Stephen P. (2005) "Survival analysis," Unpublished manuscript, Institute for Social and Economic Research, University of Essex, Colchester, UK.

Jovanovic, Boyan. (1982) "Selection and the Evolution of Industry," Econometrica, 50, 649670.

Klepper, Steven and Peter Thompson.(2006) "Submarkets and the Evolution of Market Structure," RAND Journal of Economics, 37, 861-886.

de Kok, Jan, Haibo Zhou, and Chantal Hartog. (2012) "The Risk of Growing Fast," EIM Business and Policy Research Report H201119: Zoetermeer, Netherlands.

Kosová, Renáta and Francine Lafontaine. (2010) "Survival and Growth in Retail and Service Industries: Evidence from Franchised Chains," Journal of Industrial Economics, 58, 542578.

Lopez-Garcia, Paloma and Sergio Puente. (2012) "What Makes a High-growth Firm? A Dynamic Probit Analysis Using Spanish Firm-level Data," Small Business Economics, 39, 1029-1041.

Lotti, Francesca, Enrico Santarelli, and Marco Vivarelli. (2003) "Does Gibrat's Law Hold Among Young, Small Firms?," Journal of Evolutionary Economics, 13, 213-235.

Mason, Colin and Ross Brown.(2013) "Creating Good Public Policy to Support High-growth Firms," Small Business Economics, 40, 211-225.

Mata, José, Pedro Portugal, and Paulo Guimarães. (1995) “The Survival of New Plants: Start-up Conditions and Post-entry Evolution," International Journal of Industrial Organization, 13, 459-481.

Mohr, Vivian and Elizabeth Garnsey. (2011) "How Do High-growth Firms Grow? Evidence from Cambridge, UK," Economics, Management and Financial Markets, 6, 9-43.

Musso, Patrick and Stefano Schiavo. (2008) "The Impact of Financial Constraints on Firm Survival and Growth," Journal of Evolutionary Economics, 18, 135-149.

National Endowment for Science, Technology and the Arts (NESTA). (2009) The Vital 6 $\begin{array}{llll}\text { Percent. Available online } & & & \end{array}$ at:https://www.nesta.org.uk/sites/default/files/vital-six-per-cent.pdf. 
Neumark, David, Brandon Wall, and Junfu Zhang. (2011) "Do Small Businesses Create More Jobs? New Evidence for the United States from the National Establishment Time Series," Review of Economics and Statistics, 93, 16-29.

Neumark, David, Junfu Zhang, and Brandon Wall. (2007) "Employment Dynamics and Business Relocation: New Evidence from the National Establishment Time Series," Research in Labor Economics, 26, 39-83.

Parker, Simon C., David J. Storey, and Arjen Van Witteloostuijn. (2010) "What Happens to Gazelles? The Importance of Dynamic Management Strategy," Small Business Economics, 35, 203-226.

Pérez, Silviano Esteve, Amparo Sanchis Llopis, and Juan Alberto Sanchis Llopis. (2004) "The Determinants of Survival of Spanish Manufacturing Firms," Review of Industrial Organization, 25, 251-273.

Phillips, Bruce D. and Bruce A. Kirchhoff.(1989) "Formation, Growth and Survival; Small Firm Dynamics in the US Economy," Small Business Economics, 1, 65-74.

Renski, Henry. (2011) "External Economies of Localization, Urbanization and Industrial Diversity and New Firm Survival," Papers in Regional Science, 90, 473-502.

Santarelli, Enrico and Marco Vivarelli.(2007) "Entrepreneurship and the Process of Firms' Entry, Survival and Growth," Industrial and Corporate Change, 16, 455-488.

Shane, Scott. (2009) "Why Encouraging More People to Become Entrepreneurs is Bad Public Policy," Small Business Economics, 33, 141-149.

Stam, Erik. (2010) "Growth beyond Gibrat: Firm Growth Processes and Strategies," Small Business Economics, 35, 129-135.

Stangler, Dane. (2010) "High-growth Firms and the Future of the American Economy," Kauffman Foundation Research Series: Kansas City, MO.

Storey, David J. (2011) "Optimism and Chance: The Elephants in the Entrepreneurship Room,” International Small Business Journal,29, 303-321.

Sutton, John. (1997) “Gibrat's Legacy,” Journal of Economic Literature, 35, 40-59.

van de Ven, Wynand P.M.M. and Bernard M. S. Van Praag. (1981) "The Demand for Deductibles in Private Health Insurance: A Probit Model with Sample Selection," Journal of Econometrics, 17, 229-252.

Wennberg, Karl and Göran Lindqvist. (2010) "The Effect of Clusters on the Survival and Performance of New Firms," Small Business Economics, 34, 221-241. 